ISSN: 0213-2060

DOI: http://dx.doi.org/10.14201/shhme201634271295

\title{
ASCENSO Y DECLIVE DE LA ÉLITE RURAL DE LA PUEBLA DE GUADALUPE (CÁCERES) DURANTE LOS SIGLOS XIV Y XV ${ }^{1}$
}

\author{
Rise and Decline of the Rural Elite of Puebla de Guadalupe (Cáceres) \\ in the $14^{\text {th }}$ and $15^{\text {th }}$ Centuries
}

\author{
Alfonso DOMÍNGUEZ DE LA CONCHA \\ C.e.:adomcon@gmail.com
}

Recibido: 2015-04-30

Revisado: 2015-09-04

Aceptado: 2016-10-14

RESUMEN: Este trabajo pretende una revisión del papel asignado a las élites rurales y una crítica al uso de categorías sociales rígidas. Una vez establecidos los rasgos generales que definen esta élite, pasamos a su estudio en una comunidad rural concreta. El cotejo de la documentación notarial y judicial conservada en el Archivo del Monasterio de Nuestra Señora de Guadalupe permite analizar la evolución que este grupo experimentó, durante los siglos XIV y Xv, en la red de vínculos entre los vecinos y los señores de la Puebla. La larga experiencia en los asuntos públicos le llevó a tomar conciencia de su capacidad de intervención y tratar de reafirmar su autonomía. Este proceso, en trance de consolidarse a finales del XIV, se vio truncado con la fundación del Monasterio. Los Jerónimos aplicarán un programa político y económico que liquidó la capacidad de la élite local para aglutinar a la comunidad rural. vínculos.

Palabras clave: Guadalupe; Élite rural; Heterogeneidad; Autonomía concejil; Redes de

ABSTRACT: This work aims to a review of the role of rural elites and a critique of the use of rigid social categories. Once established the general traits that define this elite, we pass

1 Siglas y abreviaturas utilizadas: $\mathrm{AMG}=$ Archivo del Monasterio de Guadalupe. $\mathrm{RAE}=$ Real Academia Española. RM= Fondo Rodríguez Moñino. 
ALFONSO DOMÍNGUEZ DE LA CONCHA

ASCENSO Y DECLIVE DE LA ÉLITE RURAL DE LA PUEBLA DE GUADALUPE (CÁCERES)

DURANTE LOS SIGLOS XIV Y XV

to study in a particular rural community. Comparison of judicial and notarial documentation preserved in the archive of the monastery of Nuestra Señora de Guadalupe allows to analyze the evolution experienced by this group, during the $14^{\text {th }}$ and $15^{\text {th }}$ Centuries, in the network of links between the neighbours and the Lords of Puebla. The long experience in public affairs led him to become aware of their capacity to intervene and try to reassert its autonomy. This process, on road to consolidation at the end of the $14^{\text {th }}$, was truncated with the foundation of the monastery. Jeronimos apply a political and economic program that liquidated the capacity of the local elite to agglutinate to the rural community. links.

Keywords: Guadalupe; Rural elite; Heterogeneity; Autonomy Council; Networks of

SUMARIO: 0 Introducción. 1 Los grupos intermedios en la historiografía anterior. 1. 1 La incorporación de los grupos intermedios a la investigación medievalista. 1. 2 Caracterización de las élites rurales. 2 Caracterización y evolución de la oligarquía en la Puebla de Guadalupe. 2. 1 La constitución de la élite (1325-1389). 2. 2 Una difícil cohabitación (1389-1425). 2. 3 La crisis de la élite local (1425-1531). 3 Conclusiones. 4 Apéndice documental. 5 Referencias bibliográficas.

\section{INTRODUCCIÓN}

Dados los presupuestos ideológicos de los paradigmas interpretativos dominantes en la segunda mitad del siglo xx, el análisis de la estructura social en el medio rural se abordaba desde la dicotomía y el antagonismo social, que reducía el espectro social a la bipolaridad privilegiados/pecheros y las relaciones a una permanente hostilidad seńores/ campesinos, sustentadas en la dominación, como bloques sociales homogéneos, de perfiles bien delimitados, sin más futuro que el enfrentamiento y la violencia.

En consecuencia, la historiografía tradicional solía atribuir un papel muy secundario a las élites locales. $\mathrm{O}$ bien se las ignoraba, o bien quedaban reducidas al papel de meros agentes ejecutores de las decisiones del señor, que no dudaban en aprovechar en beneficio propio, cuyo modo de vida imitaban y al que aspiraban a incorporarse.

\section{LOS GRUPOS INTERMEDIOS EN LA HISTORIOGRAFÍA ANTERIOR}

\subsection{La incorporación de los grupos intermedios a la investigación medievalista}

Pese a esta visión «cerrada», a partir de los años 80 y 90 del pasado siglo se observa una reconsideración de la estructura social medieval.

Varias tendencias en la investigación histórica europea (de época medieval o moderna) han colaborado a derribar el paradigma anterior. Desde finales del siglo xx, y procedente del campo de la Sociología, se introduce el término élite como categoría analítica, 
para definir al pequeño grupo de los que gobiernan y concentran la riqueza y el prestigio, en contraposición a la gran masa de los gobernados. Al convertir las élites rurales en objeto de estudio han revelado numerosos matices de aquellas que desbaratan el papel tradicionalmente asignado a los notables locales ${ }^{2}$. En segundo lugar, ofrecen una nueva percepción del campesinado en la que resalta su iniciativa y capacidad para desarrollar prácticas políticas y económicas mucho más variadas que la resignación pasiva o la mera subsistencia. Por último, procedente de la Sociología, la aplicación de una metodología de análisis relacional ha permitido superar las limitaciones de la investigación basada en categorías sociales cerradas, ofreciendo la posibilidad de aproximarse a las dinámicas sociales (grupos de poder, mercantiles y financieros, clientelares, etc) a partir de las vinculaciones efectivas entre actores sociales, y enfatizando las relaciones verticales entre grupos sociales desiguales, frente a los vínculos horizontales internos a cada grupo social ${ }^{3}$.

Más allá de su presencia en las instituciones y su destacado papel al frente de los movimientos antiseñoriales, la investigación ha mostrado otro aspecto de estas élites que tendrá consecuencias en la nueva dinámica socioeconómica que se está desarrollando en el tránsito entre la Edad Media y la Moderna: su eficacia como agente generador de transformaciones y cambios. Trabajos recientes insisten en mostrar la multiplicidad de sectores en los que están presentes, su activa participación en la producción para el mercado y la actividad comercial, así como su incorporación a los ámbitos culturales y académicos. Crece el número de los que reconocen en las familias campesinas acomodadas un grupo social diferenciado, caracterizado por el dinamismo y la versatilidad en materia económica ${ }^{4}$.

2 Entre 2003 y 2004 se publicaron una serie de artículos, dedicados a la revisión historiográfica de la investigación centrada en el mundo rural medieval, en los que se exponían, desde un planteamiento general, las nuevas tendencias (Historia Agraria. Revista de Agricultura e Historia Rural, 2003, vol. 31, pp. 9-86, y 2004, vol. 33, pp. 11-106; reeditados en Alfonso, Isabel (coord.): La historia rural de las sociedades medievales europeas: tendencias y perspectivas. València: Universitat de València, 2008). Para el tema específico de las élites véanse Menant, François y Jessenne, Jean-Pierre (eds.). Les élites rurales dans l'Europe médiévale et moderne. Toulouse: Presses Universitaires du Mirail, 2007; Furió, Antoni. «Las élites rurales en la Europa medieval y moderna. Una aproximación de conjunto». En Rodríguez, AnA (ed.). El lugar del campesino. En torno a la obra de Reyna Pastor. Valencia: Consejo Superior de Investigaciones Científicas, 2007, pp. 391-421; Carvajal de la Vega, David; Añíbarro Rodríguez, Javier y Vítores Casado, Imanol (eds.). Redes sociales y económicas en el mundo bajomedieval. Valladolid: Castilla Ediciones, 2011; Aparisi Romero, Frederic. "Las élites rurales en la Edad Media como objeto de estudio: de la marginalidad al centro del debate historiográfico». Historia. Instituciones. Documentos, 2013, vol. 40, pp. 11-34; Aparisi, Frederic y Royo, Vicent (eds.). Beyond Lords and Peasants. Rural elites and Economic Differentiation in Pre-Modern Europe. València: Universitat de València, 2014.

3 Véanse los trabajos de Imízcoz Beunza, José María. «Comunidad, red social y élites. Un análisis de la vertebración social en el Antiguo Régimen». En Imízcoz, José María (dir.). Élites, poder y red social. Las élites del País Vasco y Navarra en la Edad Moderna. Bilbao: Universidad del País Vasco, 1996, pp. 13-50; y "Las redes sociales de las élites. Conceptos, fuentes y aplicaciones». En Soria Mesa, Enrique; Bravo Caro, Juan Jesús y Delgado Barrado, José Miguel (eds.). Las élites en la época moderna: la monarquía española. Vol. I: Nuevas perspectivas. Córdoba: Universidad de Córdoba, Servicio de Publicaciones, 2009, pp. 77-112. En el último se puede encontrar abundante bibliografía.

4 Diago Hernando, Máximo. "Comerciantes campesinos en la Castilla bajomedieval y moderna: la actividad mercantil de los yangüeses entre los siglos XIV y XviI». Historia. Instituciones. Documentos, 2005, vol. 32, pp. 115-144; Borrero Fernández, Mercedes. "Élites rurales y mercado en la Andalucía bajomedieval». 


\section{ALFONSO DOMÍNGUEZ DE LA CONCHA

Todo esto ayudó a romper la empobrecedora visión dicotómica tradicional y revalorizar su papel como agente de cambio histórico. Partiendo de la consideración del medio rural como espacio en el que se desarrolló igualmente todo un sistema de relaciones y de grupos dirigentes locales, con autonomía y capacidad de gestión dentro de sus respectivos grupos humanos, adquiere sentido hablar de élites rurales. En el caso que nos ocupa hay que considerar igualmente el escaso desarrollo de la red urbana en Extremadura y la débil jerarquización del espacio, con núcleos de población muy alejados del núcleo central, que, por tanto, no podía ejercer un dominio eficaz sobre su territorio. La Puebla, además, contó con jurisdicción propia desde muy temprano y escapaba al control de los concejos urbanos próximos y de sus respectivas élites.

\subsection{Caracterización de las élites rurales}

Cuestión aparte es trazar unos rasgos más o menos definidos para estas élites rurales. Con el fin de evitar las limitaciones antes señaladas (categorizaciones rígidas y excluyentes), acudimos al análisis de las relaciones entre los sujetos. El análisis relacional no es incompatible con el clásico apoyado en categorías sociales, basadas en la presencia de atributos comunes. Los vínculos entre los individuos están mediatizados por las actividades o posesiones que definen real o simbólicamente su posición en la sociedad y por los valores y signos de identidad que se manejan como distintivos de afinidad común o de alteridad respecto de otros.

Lo cierto es que el estudio de la documentación revela la existencia de grupos intermedios en la sociedad bajomedieval. Las fuentes identifican a estos individuos como boni homines. En un primer momento, dado el dualismo predominante, se procedió a incluir estos hombres buenos en uno de los dos grandes sectores o clases sociales. O bien reproduciendo el modelo de la clase dominante, en la que intentarían integrarse, o bien constituyendo el estrato enriquecido de la clase pechera.

En comunidades reducidas, como la de la Puebla durante el siglo XIV, y de marcado carácter rural, las relaciones personales adquirían un mayor desarrollo y valoración. Lo que apoya la importancia del prestigio personal como elemento de diferenciación social, más que el origen. En estas comunidades de la Extremadura castellana habría pocos nobles y predominaba una cierta igualdad social, favorecida en el caso de la Puebla de Guadalupe por estar formada a partir de la agregación de elementos heterogéneos -peregrinos-, cuya extracción social humilde sería mayoritaria (por no decir absoluta). En una primera etapa no habría distinción en cuanto a su extracción social. Se primaría su posición económica y sus cualidades personales, pues lo que les distinguiría sería el prestigio alcanzado entre sus convecinos. Esta situación favorecería su acceso al concejo por ser considerados más aptos para el desempeño de los oficios municipales. Con el tiempo se incorporarán individuos procedentes de los sectores económicos emergentes (artesanía, comercio) y no solo de la propiedad rústica.

En Pautes de consum i nivells de vida al món rural medieval. Coloquio Internacional. València: Univiversitat de València, 2008, disponible en http://www.uv.es/consum/textos.htm (conexión el 21 de julio de 2011). 


\section{ALFONSO DOMÍNGUEZ DE LA CONCHA \\ ASCENSO Y DECLIVE DE LA ÉLITE RURAL DE LA PUEBLA DE GUADALUPE (CÁCERES) DURANTE LOS SIGLOS XIV Y XV}

Para la investigación anterior dos aspectos destacan a la hora de definir este grupo: a una sólida base económica se añadieron otros de carácter moral y de conocimiento. Todos ellos les proporcionaban prestigio ante sus convecinos. Esta posición les confería la posibilidad de desarrollar una participación activa en los asuntos que concernían a la comunidad. Su posición les permitía generar redes de vínculos y clientelas: mediante la contratación de asalariados, la concesión de préstamos, la resolución de crisis frumentarias, la gestión de los bienes comunales en condiciones ventajosas para sus clientelas, etc.; y desarrollar una lógica política propia, apoyada en el «capital relacional» y la «capacidad de acción» que ofrecían las clientelas generadas en su entorno 5 .

En el mundo rural, como en el urbano, se observa una progresiva toma de conciencia de su capacidad de organización e intervención política y económica. Los grupos emergentes de pecheros buscarían un mayor protagonismo en la defensa de sus intereses y el acceso a los órganos de gobierno y dirección ${ }^{6}$. Esto los situará al frente de los movimientos de resistencia antiseñorial, suscitando la cohesión del Común en torno a ellos. Eran los que contaban con capacidad real para dirigir el movimiento, dada su capacidad de autoorganización, su dominio del lenguaje procesal y su experiencia en la práctica legal ${ }^{7}$.

Por su parte, los señores de los concejos manifestaron su interés por comprometer a miembros del común en la gestión de gobierno, por el papel que los notables del común asumían en tareas organizativas y de gestión municipal; especialmente en la fiscalidad y las tareas anejas ${ }^{8}$. Un buen instrumento para estos fines era la creación de una tupida red de vínculos clientelares?

5 Imízcoz Beunza, «Comunidad, red social y élites», pp. 13-14 y 30; Schofield, Phillipp R. Peasant and community in late medieval England, 1200-1500. Basingstoke: Palgrave Macmillan, 2003; MondraGóN, Silvina Andrea. «Participación política de pecheros en Castilla tardomedieval: los posibles márgenes de acción entre la diferenciación socioeconómica del sector y la imposición de concejo cerrado». Espacio, Tiempo y Forma. Serie III, H. ${ }^{a}$ Medieval, 2012, vol. 25, pp. 309-326.

6 Monsalvo Antón, José María. «La participación política de los pecheros en los municipios castellanos durante la Baja Edad Media. Aspectos organizativos». Studia Historica. Historia Medieval, 1989 , vol. 7, pp. 37-93; Astarita, Carlos. «Representación política de los tributarios y lucha de clases en los concejos medievales de Castilla». Studia Historica. Historia Medieval, 1997, vol. 15, pp. 139-169 [140]; Luchía, Corina. «Dos memoriales de agravios de Ciudad Rodrigo: el diálogo político entre pecheros, élites y monarquía en torno del ejercicio del poder». Actas y Comunicaciones del Instituto de Historia Antigua y Medieval, 2013, vol. 9, pp. 1-15 [4]; Mondragón, «Participación política de pecheros en Castilla», p. 317.

7 Lorenzo Cadarso, Pedro Luis. Los conflictos populares en Castilla (siglos XVI-XVII). Madrid: Siglo XXI de España Editores, 1996, pp. 147-148.

8 Martínez Sopena, Pascual. La Tierra de Campos Occidental. Poblamiento, poder y comunidad del siglo X al XIII. Valladolid: Institución Cultural Simancas. Diputación Provincial de Valladolid. 1985, p. 513; Casado Alonso, Hilario. "Solidaridades campesinas en Burgos a fines de la Edad Media». En Pastor, Reyna (comp.). Relaciones de poder, de producción y parentesco en la Edad Media y Moderna. Aproximación a su estudio. Madrid: Consejo Superior de Investigaciones Científicas, 1990, pp. 279-304 [298]; Astarita, Carlos. Del feudalismo al capitalismo. Cambio social y politico en Castilla y Europa occidental: 1250-1520. València: Universitat de València, 2005, p. 115.

9 Alfonso Antón, Isabel. «Poder local y diferenciación interna en las comunidades rurales gallegas». En Pastor, Relaciones de poder, de producción y parentesco, pp. 203-223 [222]. Imízcoz Beunza, "Comunidad, red social y élites», pp. 13-14 y 30. 


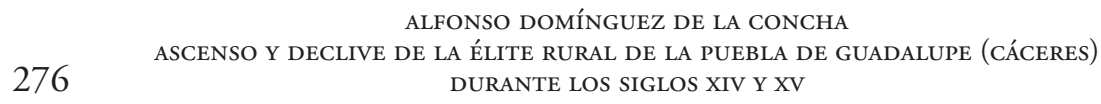

2 Caracterización y evolución de la oligarquía en la Puebla de Guadalupe

\subsection{La constitución de la élite (1325-1389)}

Una vez establecidos los rasgos generales que definen esta élite, pasamos a su estudio en una comunidad rural, tomando como ejemplo la Puebla de Guadalupe. Nos centraremos en el grupo social que la propia comunidad identificó como su élite dirigente, con la denominación de hombres buenos. El cotejo de los documentos conservados en el Archivo del Monasterio de Nuestra Señora de Guadalupe ha permitido elaborar una lista de estas personas. El siguiente paso será analizar la evolución que experimentó este grupo a lo largo de los siglos XIV y XV en su posición central en la red de vínculos entre los vecinos y los señores de la Puebla.

La Puebla de Guadalupe, como núcleo estable de población, surge en una fecha imprecisa de la segunda mitad del siglo XIII ${ }^{\mathrm{IO}}$. Sus características iniciales son mal conocidas. La principal fuente de información procede de las autoridades eclesiásticas del santuario, que trataron en todo momento de transmitir la imagen de una comunidad rural carente de capacidad de autogobierno y supeditada al señorío de los priores, tanto seculares como regulares.

Así, cuando el 11 de mayo de 1338 se procede a delimitar el término concedido a la iglesia por Alfonso XI, no se mencionan hombres buenos o un concejo propio y en ningún momento se dice que estuviesen presentes vecinos o moradores. Tal y como está redactado el documento se da a entender que el lugar estaba despoblado. No interesaba dejar constancia de un grupo de pobladores consolidado, porque, por pequeño que fuese, podía reclamar la titularidad sobre el término y autonomía para gobernarse. No obstante, lo exiguo de la población y el origen de la misma (aluvión de personas pobres que buscarían la protección de la iglesia) no daría lugar a una diferenciación interna que generase una élite local.

El primer cambio importante lo encontramos en 1347, cuando Alfonso XI confirma el término concedido 10 ańos antes ${ }^{11}$. Por primera ver se hace referencia directa a la presencia de hombres buenos en Guadalupe que pudieran formar parte de un concejo: según declara el monarca en su carta, la iniciativa partió de los «onmes buenos de la dicha eglesia e de la dicha puebla del dicho lugar de Santa María de Guadalupe». No solo eso, además ejercían competencias en materia de recaudación y policía. Así lo da a entender el monarca cuando establece que quienes incumplan lo establecido «y entren a pasçer e a cortar lenna en el dicho término que peche por cada vegada diez mrs de la dicha moneda a los onmes buenos del dicho lugar». Y añade que «mandamos a los onmes buenos del dicho lugar que den onmes de entre sí que guarden el dicho término».

Es el primer documento en el que se muestra la existencia de dos entes con personalidad propia. Sin embargo, las competencias estarían poco definidas; lo que favorecería la

10 No existe una carta-puebla ni otro documento que ofrezca una fecha precisa para el origen de Guadalupe. Posiblemente hubo un núcleo anterior de población inestable (pastores, colmeneros). Del análisis interno de la leyenda de la aparición de la Virgen al pastor y de otras fuentes se colige que el lugar se consolidó durante el reinado de Alfonso X.

11 AHN. Clero. Carpeta 391, n. ${ }^{\circ}$ 19, positivo 2461. 


$$
\begin{gathered}
\text { ALFONSO DOMÍNGUEZ DE LA CONCHA } \\
\text { ASCENSO Y DECLIVE DE LA ÉLITE RURAL DE LA PUEBLA DE GUADALUPE (CÁCERES) } \\
\text { DURANTE LOS SIGLOS XIV Y XV }
\end{gathered}
$$

usurpación de funciones por los gestores del santuario. Los priores, o sus lugartenientes, ejercerían el control de facto sobre la Puebla; hasta el privilegio de 1348, por el que Alfonso XI concede la jurisdicción civil a los priores, que lo harían de derecho.

En 1348 Alfonso XI presenta a Toribio Fernández como prior de la iglesia. En otra parte presentamos los argumentos que nos llevan a considerar que este documento fue manipulado. Intercaladas entre el texto original se insertaría la concesión del señorío y de la jurisdicción, como si fuesen dos más de los méritos que el rey alegaba en defensa de su derecho de patronazgo, con la intención de legalizar la situación de facto en el gobierno de la Puebla. Gracias a él se obtenía la sanción jurídica al gobierno del prior sobre la población. Vemos en ello la reacción del prior a una creciente conflictividad con los vecinos del lugar, privados de amplias competencias en materia de gobierno. En apoyo a esta hipótesis se puede argüir que, pese a la pretendida entrega de la jurisdicción señorial sobre la Puebla, en el período previo a la donación por Enrique II del mero y mixto imperio (1368) los cargos públicos se identifican como nombrados por el rey (a merced del rrey). Así ocurre con la totalidad de los escribanos y alguno de los alcaldes que se han podido documentar.

En paralelo al proceso señorializador, asistimos a la gestación de una minoría diferenciada dentro de la comunidad guadalupense a mediados del XIV. Y los caminos para conseguirlo fueron variados.

Durante el priorato de Toribio Fernández de Mena se consolidó un grupo de personas que gozaban de la confianza del prior y este delegaba funciones en ellos (fuera de la Puebla-como «criados»-y dentro - como oficiales concejiles-), a las que denominaremos «vieja» oligarquía. El prior creó su propia red clientelar, que permitía ampliar su «capital relacional» para extender y hacer efectivo su poder. Aunque el protagonismo del prior se mantiene -en la partición de las tierras de Pasarón de 1352 intervino directamente ${ }^{12}-$, parece que esta misma actividad, desplegada en numerosos campos de acción, obligó al prior a delegar en personas de su confianza. Primero lo hará en el personal eclesiástico bajo su autoridad inmediata, pero utilizará cada vez más la figura del procurador seglar. Esta actividad favorecerá que surja una élite local. Su proximidad a la máxima autoridad y su capacidad para actuar de intermediarios entre la comunidad y el señor reforzaría su posición. Así se observa en 1354, en la compraventa de unos bienes en Cañamero: todos los testigos eran vecinos de Guadalupe. Con la particularidad de que por primera vez serán identificados como hombres buenos ${ }^{13}$.

Entre 1362 y 1366 se venden varias propiedades en el área de Madrigalejo. En todos los casos el escribano recibió la propiedad «en nonbre de la dicha eglesia e prior», cumpliendo el mismo cometido que los procuradores. De tal manera que la integración del personal administrativo en el servicio directo de los priores aparece como otra de las vías de promoción ${ }^{14}$.

\section{AHN. Clero. Carpeta 393, n. ${ }^{\circ} 6$.}

AMG. Legajo 120, n. ${ }^{\circ} 41$.

14 De hecho, el acceso al notariado se convirtió en una estrategia de promoción social entre las élites rurales durante el siglo Xv; practicada no solo por terratenientes, sino también por familias ligadas al sector secundario (Aparisi Romero, Frederic. «The notarial profession as a means of social promotion amongst 
ALFONSO DOMÍNGUEZ DE LA CONCHA

ASCENSO Y DECLIVE DE LA ÉLITE RURAL DE LA PUEBLA DE GUADALUPE (CÁCERES)
DURANTE LOS SIGLOS XIV Y XV

Estas fechas coinciden con una etapa de desarrollo de las hermandades de ballesteros y colmeneros ${ }^{15}$. Además de aportar pobladores pudo ser otra vía de promoción para los propietarios de colmenares asentados en la zona, dado que los hombres buenos con intereses apícolas se integraron en los órganos de dirección de su hermandad ${ }^{16}$. Los cuadrilleros serían el eslabón que pudo permitir el ascenso social a los pecheros rurales con más iniciativa y recursos. Como, por ejemplo, los numerosos ballesteros mencionados en la documentación de Guadalupe desde que surgió el santuario (en la delimitación del término de 1338 ya se cita una «Fuente de los Ballesteros») ${ }^{17}$.

Como otros muchos miembros de la alta nobleza, los priores contaban con un séquito, en el que se incluían familiares que podían intervenir en alguno de estos actos. Así se comprueba en 1374 cuando Pedro Manrique, adelantado mayor de Castilla, dona a la iglesia de Guadalupe su villa de Vea ${ }^{18}$; entre los testigos aparecen Juan Díaz Machuca, primo del prior Diego Fernández, y Fernando Gudiel, sobrino del prior. La misma situación estuvo presente ese ańo, cuando se toma posesión de la heredad de Santa María de la Vega. El prior otorgó un poder a otro sobrino, Gutierre Fernández, para que actuase en su nombre ${ }^{19}$. Es razonable plantear que en este séquito también pudieron participar personas sin vínculo familiar con el prior.

La posición de los priores en el entramado social y el reconocimiento de su autoridad por parte de la élite del momento se aprecia en el testamento de dońa Leonor (1349), al referirse la testadora a don Toribio como el prior mi sennor ${ }^{20}$. Al menos se observa las buenas relaciones entre ambas partes (doña Leonor le encomienda «que cate por mi padre aquí como cataua por mí»).

No obstante, es posible que no fuesen tan firmes como la documentación da a entender. En 1359 Pedro I revoca el nombramiento de Juan Fernández de Talavera como alguacil, a petición del prior. No se sabe qué relación pudo tener Juan con la Puebla o la élite local (el monarca se limita a señalar que era su repostero), pero la rápida reacción del prior pudiera deberse a la existencia de tensiones no reflejadas en las crónicas.

Así parece desprenderse de otro suceso. Ese mismo año (1359) el monarca conmina a los «onmes buenos vezinos e moradores» de Guadalupe a que paguen al prior sus pechos y derechos ${ }^{21}$. La iniciativa del rechazo a pagar había partido de «uos los onmes

rural elites in the midlands of the Kingdom of Valencia during the Later Middle Ages». En ApARISI y Royo (eds.), Beyond Lords and Peasants, pp. 139-162).

15 Las de Talavera y Toledo existían desde al menos 1300 (SÁnchez Benito, José María. «Hermandades y delincuencia rural entre el Tajo y Sierra Morena (siglos XIII-Xv)». Clio \& Crimen, 2006, vol. 3, pp. 134-166 [140]).

16 De hecho, eran quienes la dirigían (SÁnchez Benito, José María. «La Hermandad de los Montes de Toledo entre los siglos XIV-Xv». Espacio, Tiempo y Forma. Serie III, H. a Medieval, 2005, vol. 18, pp. 209229 [222]; ÍDEM, «Hermandades y delincuencia rural», p. 141).

17 En Guadalupe están documentados once ballesteros durante los siglos XIV y Xv. Destacamos a Martín Pérez, por sus servicios al prior, y a Juan Rodríguez, por su activa participación en el mercado de la tierra. Ambos ricos propietarios.

18 AHN. Clero. Carpeta 396, n. ${ }^{\circ} 11$, positivo 2461.

19 AHN. Clero. Carpeta 396, n. ${ }^{\circ}$ 10, positivo 2461.

20 AMG. Legajo 45, n. ${ }^{\circ} 105$.

21 AHN. Clero. Legajo 1422, n. ${ }^{\circ} 11$; AHN. Carpeta 4000, n. ${ }^{\circ} 11$, positivo 3267. 


$$
\begin{gathered}
\text { ALFONSO DOMÍNGUEZ DE LA CONCHA } \\
\text { ASCENSO Y DECLIVE DE LA ÉLITE RURAL DE LA PUEBLA DE GUADALUPE (CÁCERES) } \\
\text { DURANTE LOS SIGLOS XIV Y XV }
\end{gathered}
$$

buenos vezinos e moradores ý en el dicho lugar o algunos de uos». Estaríamos ante una primera reacción frente a la presión señorializadora, manifestada en la negativa a reconocer al prior la potestad recaudatoria.

El testamento de Sancho Fernández (1363), criado de mi sennor el prior, revela varios de los aspectos de esta élite. Se trata de una persona al servicio del prior, que obtiene a cambio regalos y prebendas. Sancho debió ejecutar ciertos cometidos en Sevilla y el prior recompensó su trabajo con un obsequio ${ }^{22}$. Es posible que se viese beneficiado por otras mercedes, como la entrega de tierras; o su desahogada posición económica, favorecida por su proximidad al prior, le permitió hacerse con ellas. Creemos que el topónimo «Nava de Sancho Fernández», localizado al SO del término de Guadalupe (zona de expansión agrícola durante el siglo XIv), habría que ponerlo en relación con este personaje.

La generosidad del prior al recompesar su actividad y los beneficios obtenidos gracias a sus cargos públicos les otorgarían una sólida base económica. Estos personajes se convertirán en los cabeza de grupo familiar de las familias que conformarán la vieja oligarquía de Guadalupe. Esta aparente reciprocidad (servicios a cambio de beneficios) era selectiva y desequilibrada. Generaba diferenciación social al establecer relaciones preferentes con algunos miembros de los grupos poderosos locales ${ }^{23}$. Y tenía sus inconvenientes, pues originaba bandos enfrentados.

Con la donación de la jurisdicción civil y criminal por Enrique II (1368) los priores asumen el control sobre el gobierno de la Puebla, eliminando toda posible contestación al ejercicio de la jurisdicción señorial ${ }^{24}$. Se favorecen los vínculos con las autoridades locales -que pueden prestar servicios a cambio de gratificaciones-, promocionando a los miembros que manifiestan una capacidad real para influir en la comunidad, con el fin de formar una élite adepta que articulase las relaciones con la comunidad local y les permitiese penetrar en la red de vínculos locales.

Prueba del control que los priores mantienen sobre la gobernación es que cuando en 1369 el rey Enrique II ordena a los concejos limítrofes que permitan a la iglesia de Guadalupe sacar viandas de sus términos lo hace a petición del prior ${ }^{25}$. Más allá del evidente beneficio que esta práctica tenía sobre la población, el abastecimiento en época de malas cosechas o carestía tenía consecuencias directas sobre el entramado de relaciones. Ofrecía una oportunidad para amplificar prácticas caritativas, permitiendo desarrollar todo un entramado de reciprocidades ${ }^{26}$. En Guadalupe este papel lo ocupó el monasterio, privando a la élite (que eran los principales propietarios de tierras cerealeras) de un medio para generar y fortalecer vínculos de dependencia.

22 "Una taça de plata de marco e medio que me dio el prior mi sennor quando vine de Sevilla» (AMG. Legajo 45, n.o 24).

23 Rodríguez, Ana María y Pastor, Reyna. «Reciprocidades, intercambio y jerarquía en las comunidades medievales». Hispania, 2000, vol. LX/1, n.o 204, pp. 63-101 [73].

24 AHN. Clero. Carpeta 395, n. ${ }^{\circ} 14$.

25 Cerro Herranz, M. ${ }^{a}$ Filomena. Documentación del monasterio de Guadalupe. Siglo XIV. Badajoz: Departamento de Publicaciones de la Excma. Diputación Provincial de Badajoz, 1987, doc. n.o 112.

26 Oliva Herrer, Hipólito Rafael. «Reacciones a la crisis de 1504 en el mundo rural castellano». En Oliva Herrer, Hipólito Rafael y Benito I Monclús, Pere (eds.). Crisis de subsistencia y crisis agrarias en la Edad Media. Sevilla: Universidad de Sevilla, Secretariado de Publicaciones, 2007, pp. 259-275 [275]. 
A partir de 1368 la vinculación al prior no será la única vía de ascenso social. Enrique II concedió una feria anual y un mercado semanal ${ }^{27}$. El prior pretendía impulsar el desarrollo económico de la Puebla, como medio para fijar la población («e porque en ella sea más ennoblesçida e otrosý por que vezinos e moradores en la su puebla sean más ricos»), y tuvo como corolario la consolidación de los sectores artesanales y comerciales, cuya posición económica serviría de trampolín para aspirar a entrar en el grupo de gobierno local; constituyendo, junto con los terratenientes y burócratas, uno de los puntales de la oligarquía del momento.

El cambio en la estructura social se aprecia en la composición del grupo de hombres buenos. Si durante el tercer cuarto del siglo XIV se constata un claro predominio de oficiales concejiles entre sus miembros, durante el último cuarto del mismo y primera década del Xv ceden el protagonismo a elementos procedentes del ámbito de la artesanía y el comercio, deseosos de participar en la toma de decisiones de acuerdo con su potencial socio-económico.

La extracción social de varios de estos personajes pone en duda una de las características que la investigación anterior atribuía a los hombres buenos: su identificación con los estratos enriquecidos de la sociedad. Los carreteros, recueros o carniceros pudieron hacer fortuna, pero dificilmente se puede suponer una saneada posición económica a quien era un pastor de vacas (Alfonso Fernández -1395-), un albardero (Juan Sánchez -1395-), un sastre (Juan González -1401-), pregoneros (Diego Gil -1395- y Gonzalo Matheos -1402-), un operario de la industria textil (Alfonso González, tundidor, -1406-) o unos albañiles (Mateo Sánchez -1406- y Juan Álvarez -1408-). Es decir, la riqueza, con ser importante, no fue un factor decisivo para ser reconocido como miembro de la élite local.

Esta posición periférica respecto de uno de los mecanismos fundamentales para influir en la comunidad lleva a plantear qué fue lo que posibilitó que estas personas obtuviesen el reconocimiento de sus convecinos. La clave parece girar en torno a la noción de prestigio. ¿Cómo lo alcanzaron? La respuesta inmediata nos llevaría a recordar su capacidad para contratar mano de obra, dada su condición mayoritaria de propietarios de extensas explotaciones agrícolas, que requerían de esta fuerza de trabajo. Pero nos aventuramos a proponer otra alternativa, que no es contradictoria: su vinculación con el santuario. En dos planos: por ser personas que manifestaban una especial religiosidad o espiritualidad y por su nexo con la autoridad señorial. Se ha comprobado que las familias que componían la élite local aparecen asociadas con frecuencia a instituciones benéficoasistenciales (cofradías, hospitales, beaterios, etc.) - dentro de la comunidad de la Puebla entre los pecheros solo este grupo social contaba con la capacidad económica suficiente para crear estos establecimientos-. Erigirlos permitía manifestar su poder, pero al mismo tiempo confería un prestigio y una capacidad para influir sobre sus convecinos necesarios para consolidar aquel. Será otra de las actividades que el Monasterio arrebatará a la élite local, durante la primera mitad del siglo Xv, asumiendo competencias exclusivas.

La otra vía sería el servicio directo a los gestores del cenobio. Entre los hombres buenos documentados aparecen Domingo Juan «de las mandas» (1401) y Domingo García «de las mandas» (1402, 1408, 1409), ambos relacionados con la recaudación

27 AHN. Clero. Carpeta 395, n. ${ }^{\circ} 1$. 
de los donativos que los creyentes entregaban para el santuario. Otro ejemplo sería Miguel Sánchez «de los pobres»-seguramente encargado de atender a los peregrinos y menesterosos que acudían al santuario-, citado como hombre bueno en 1409; así como su hijo Lorenzo Martín, recuero (1408).

Estos dos elementos nos llevan a proponer que otra característica identitaria de una parte de la vieja oligarquía sería su percepción e identificación como cristianos viejos. Aspecto nada desdeñable como elemento de alteridad frente a la nueva oligarquía, constituida en buena medida por elementos judeo-conversos.

El prior Diego Fernández mantuvo la política de delegar funciones en seglares y acude a quienes componen el grupo de gobierno "oficioso»: en la venta de una parte de Valdepalacios (1375) todos los testigos serán identificados como hombres buenos ${ }^{28}$, si bien bajo su priorato parece que el espectro de electos será cada vez más reducido y se centrará en la élite que ya había accedido también a los oficios públicos. Esta política favorecerá la consolidación de este grupo de notables, pero, como efecto secundario, cerrará el acceso a otros grupos familiares. Esta primera generación presenta un rasgo común: cuando son citados no se especifica oficio alguno ${ }^{29}$. Por ello, y por las características de su patrimonio (fundamentalmente agrario), planteamos que eran propietarios agrícolas (terratenientes) $^{30}$.

En 1379 se data uno de los pocos documentos en los que es posible vislumbrar la existencia de un concejo propio en la Puebla de Guadalupe. En dicha fecha se redacta un traslado del privilegio de Enrique II de 1373 (exención de alcabalas y pechos) ${ }^{31}$. La petición la presentaron conjuntamente el prior, Diego Fernández, y el escribano Domingo Estevan. Lo más importante es que, según recoge el texto, Domingo intervino "por sý e por nonbre del conçejo del dicho logar». Y más tarde añade que la petición se realiza «otrosý por razón que los dichos onmes buenos por sý e por nonbre del conçejo del dicho logar se esperaban aprovechar de la dicha carta. E por quanto el dicho prior la tenía en su guarda».

Varios aspectos cabe señalar. En primer lugar, la existencia de un órgano de representación propio de la comunidad de Guadalupe, dotado de cierta autonomía frente al prior. En segundo lugar, la presencia de la élite local a la cabeza del mismo. Por último, que la autoridad eclesial pretendía ejercer un severo control sobre todos los aspectos del gobierno de la Puebla, manteniendo en su poder documentación que en realidad correspondía a la comunidad.

Una conclusión que se puede sacar de todo ello es que, en el cambiante juego de intereses y revisión del equilibrio de poderes, el enfrentamiento entre el prior y la élite local

28 AHN. Clero. Carpeta 396, n.o 16, positivo 2461.

29 Los enfrentamientos entre subgrupos oligárquicos, por el control de los oficios concejiles, será una constante en los concejos (Monsalvo Antón, «La participación politica de los pecheros»).

30 No debemos descartar que la política económica de los priores, tendente a obtener de los reyes ventajas económicas que consolidasen la repoblación del lugar, facilitase la incorporación de personas que ya contaban con bienes en la zona. Fenómeno constatado, por ejemplo, en la villa de Cifuentes (GraÑa Cid, María del Mar. «Urbanización y conexiones con el medio agrario durante la Baja Edad Media: el ejemplo de la villa alcarreña de Cifuentes». En la España Medieval, 1992, vol. 15, pp. 121-135).

31 AHN. Clero. Carpeta 396, n. ${ }^{\circ}$ 6, positivo 2461. 
ALFONSO DOMÍNGUEZ DE LA CONCHA

ASCENSO Y DECLIVE DE LA ÉLITE RURAL DE LA PUEBLA DE GUADALUPE (CÁCERES)

DURANTE LOS SIGLOS XIV Y XV

habría alcanzado cotas de gran virulencia, viéndose obligado aquel a solicitar continuas confirmaciones reales de los privilegios, para reforzar su débil autoridad.

A finales del siglo XIV esta élite local ya no estaría formada por individualidades destacadas, sino por verdaderos grupos familiares, cuyos miembros acapararían los oficios públicos, como se puede comprobar en la reiteración de personas en el mismo oficio o de varias generaciones de familiares en diferentes cargos. Pero su espectro cada vez más reducido pudo generar tensiones internas en la élite. Algunos grupos familiares o individuos pudieron sentirse postergados y recelosos ante el protagonismo de los «favorecidos» por el prior. El esquema sería similar al observado en las ciudades, con la consiguiente aparición de sectores o bandos enfrentados ${ }^{32}$. La permanente ausencia del prior don Juan Serrano (no estará presente en ninguna de las operaciones de compraventa conocidas) fomentó que esta élite actuase al margen de los intereses de la iglesia y su cabeza.

Los largos años de gestión de los asuntos públicos les llevaría a tomar conciencia de su capacidad de acción política y de influencia sobre sus convecinos. Y a defender su posición frente al poder prioral. El fenómeno viene de atrás, pero se revelaría con todo vigor en estas fechas. Este ataque al señorío de los priores, y no el quebranto de la moral pública, sería la verdadera causa de la erección del monasterio. El paso siguiente sería entregar el santuario a una persona o institución capaz de ejercer un estrecho control sobre la comunidad rural de Guadalupe, aunque el proceso se camuflase bajo la imagen del espíritu de reforma auspiciado por don Pedro Tenorio, arzobispo de Toledo, y por el rey Juan $\mathrm{I}^{33}$.

\subsection{Una difícil cohabitación (1389-1425)}

En la toma de posesión de la Puebla por los Jerónimos (28-10-1389) se dice que estaban reunidos los alcaldes, el alguacil «e otros muchos onmes buenos del conçeio del dicho logar Guadalupe llamados a conçejo por mandado del dicho sennor obispo a

32 García Oliva, M. ${ }^{a}$ Dolores. Organización económica y social del concejo de Cáceres en la Baja Edad Media. Cáceres: Institución Cultural El Brocense. Excma. Diputación Provincial de Cáceres, 1990; QuiNTanilla Raso, M. a Concepción. "Política ciudadana y jerarquización del poder. Bandos y parcialidades en Cuenca». En la España Medieval, 1997, vol. 20, pp. 219-250; MARTín CEA, Juan Carlos. El mundo rural castellano a fines de la Edad Media. El ejemplo de Paredes de Nava en el siglo XV. Valladolid: Junta de Castilla y León, 1991; Goicolea Julián, Francisco Javier. "Sociedad y relaciones de poder en una ciudad riojana a fines del Medievo: Santo Domingo de la Calzada». Espacio, Tiempo y Forma. Serie III, H. a Medieval, 1999, vol. 12, pp. 243-286; MuÑoz Gómez, Víctor. «La participación política de las élites locales en el gobierno de las ciudades castellanas en la Baja Edad Media. Bandos y conflictos de intereses (Paredes de Nava, final del s. xIV-inicio del s. xv)». Anuario de Estudios Medievales, 2009, vol. 39/1, pp. 275-305.

33 Para José Manuel Nieto los monarcas consideraron como una competencia propia la actuación en materia de reforma eclesiástica (Nieto Soria, José Manuel. «Iglesia y orígenes del Estado moderno en la Castilla Trastámara». Espacio, Tiempo y Forma. Serie III, H. a Medieval, 1991, vol. 4, pp. 137-160 [150]). Para la intervención del arzobispo de Toledo vid. SÁnchez Sesa, Rafael. «Don Pedro Tenorio y la reforma de las Órdenes monásticas en el último tercio del siglo xIv. La vinculación del prelado a la espiritualidad jerónima». En la España Medieval, 1995, vol. 18, pp. 289-302. 


$$
\begin{gathered}
\text { ALFONSO DOMÍNGUEZ DE LA CONCHA } \\
\text { ASCENSO Y DECLIVE DE LA ÉLITE RURAL DE LA PUEBLA DE GUADALUPE (CÁCERES) } \\
\text { DURANTE LOS SIGLOS XIV Y XV }
\end{gathered}
$$

canpana rrepicada ${ }^{34}$, quienes, si no un concejo en sentido estricto, sí podían constituir un grupo de gobierno del lugar, que actuaba en nombre del resto de la comunidad.

A la nueva autoridad señorial le interesaba contar con el apoyo de una minoría bien integrada en la comunidad, con una posición dominante y con capacidad para influir en sus convecinos. De esta manera podía extender su red clientelar por todos los estratos de la sociedad y favorecer su integración en las estructuras sociales y la aceptación de su posición dominante. Por ello al principio los Jerónimos toleraron la presencia de un pseudoconcejo autónomo o núcleo de gobierno formado por la vieja oligarquía, para más tarde crear sus propias estructuras de poder; siempre y cuando su poder no fuese excesivo. La actitud desafiante de este grupo llevó a los priores regulares a desarrollar estrategias encaminadas a debilitar su posición tanto económica como social.

La nueva política introducida por el Monasterio, otorgándoles un margen de acción controlada, una autonomía vigilada, exacerbaría los ánimos de este grupo acostumbrado a gobernar la Puebla. El núcleo estaría formado por los principales cargos concejiles -dos alcaldes y un alguacil- al que se unirían el resto de los oficiales y los escribanos. Con la toma de posesión por los monjes este órgano desaparecerá y los priores ejercerán el control directo. En un primer momento aún confiarán en esta vieja oligarquía y acudirán a sus más destacados miembros para que actúen en su nombre. Pero la posición subalterna de todos los vecinos, su consideración como vasallos del prior, quedará patente desde el principio. Así se manifestará tanto en la avenencia con los moradores de Valdepalacios (1392) como en la confirmación por Enrique III del vasallaje de aquellos (1393) ${ }^{35}$.

Frente a este grupo levantisco el Monasterio promocionará una "nueva» oligarquía. Formada por personal dependiente, integrado tanto en la administración como en los oficios públicos. Compartirán otras dos características: no forman parte de las antiguas familias ricas (algunos incluso son foráneos) y posiblemente muchos eran judíos o conversos (extremo difícil de comprobar, dada la tendencia a eliminar todo rastro de sus orígenes). La denominamos «nueva» por la renovación de las personas y «oligarquía» por su posición estructural, aunque sus bases y funciones sean bien distintas a las de la «vieja».

A lo que no estaban dispuestos los priores era a que surgiese una nueva élite que pudiera convertirse en otro núcleo de contestación a su posición dominante. Quieren oficiales que actúen como intermediarios o ejecutores de su política y mantengan una clara dependencia respecto de las autoridades eclesiásticas. Están dispuestos a conferirles prestigio ante sus convecinos, pero sin entregarles recursos que les permitieran consolidarse como alternativa. Muestra del declive experimentado por la élite local, su desestructuración y el papel que le tenía reservado el Monasterio es que, aunque oficiales concejiles, carece de una base económica saneada. El análisis de sus bienes raíces revela la ausencia de grandes propiedades agrícolas e, incluso, inmuebles. Muchos vivían en casas a censo del monasterio y sus ingresos procedían de sus salarios, siempre expuestos a las devaluaciones monetarias. Es decir, abocados al empobrecimiento.

34 AHN. Clero. Carpeta 398, n. ${ }^{\circ} 4$.

35 AHN. Clero. Legajo 1423, n. 35 (antes 74); y AHN. Clero. Carpeta 398, n. ${ }^{\circ}$ 19, positivo 2461, respectivamente. 


\section{4 ASCENSO Y DECLIVE DE LA ÉLITE RURAL DE LA PUEBLA DE GUADALUPE (CÁCERES) DURANTE LOS SIGLOS XIV Y XV}

El concejo desaparece como institución formal (si es que alguna vez lo fue), asumiendo el Monasterio el control directo de la vida política y socioeconómica de la Puebla. Pero los priores delegarán en los hombres buenos en aquellos actos que afectasen directamente los intereses de los vecinos; y participarán solo como representantes de estos. Como en 1401, cuando un grupo de hombres (que no reciben apelativo alguno, pero que podemos identificar como pertenecientes a la élite) arriendan una parte del término de Talavera, en nombre y para beneficio de los vecinos y moradores de la Puebla ${ }^{36}$.

Solo cuatro años más tarde, en 1406, la Puebla se vió sacudida por uno de los primeros tumultos antiseńoriales. Las crónicas que recogen estos sucesos coinciden en que el prior Fernandiáńez se dirigió a los jefes del levantamiento identificándolos como hombres buenos $^{37}$. Aunque el término se utilizase para designar a los cabecillas, la sentencia posterior utilizará la expresión para referirse con carácter general a todos los vecinos y moradores y no solo a los promotores del movimiento (que eran miembros de la vieja oligarquía, al igual que los procuradores rebeldes). Es decir, a comienzos del siglo XV no está claro si la expresión se aplicaba con carácter general a todos los pobladores o solo a una fracción concreta; la homogeneización de la comunidad cada vez es más patente. No obstante, hay que considerar que la fuente documental procede del sector eclesiástico, por lo que puede ser una visión interesada que trate de mostrar una realidad social uniforme, pues considera a todos como sus vasallos.

La sentencia dada contra el movimiento parece aportar datos de un posible enfrentamiento entre sectores sociales. Cuando se enumeran los testigos presentes a los diferentes actos, se refiere a ellos indistintamente como hombres buenos o como vecinos; pero entre estos últimos constatamos la presencia de algunos miembros de la élite. El vocabulario tal vez refleje que la vieja oligarquía se había fracturado en dos bandos: uno "pro Monasterio», que procurase su ascenso social a la sombra de la nueva autoridad eclesiástica; y otro "anti Monasterio», formado por ricos propietarios que habrían quedado relegados del gobierno de la Puebla y por elementos de la fracción más exaltada de los cristianos viejos. Lo cierto es que entre los rebeldes condenados figuran miembros destacados del sector terrateniente postergado en el concejo. Se nos viene a la mente el «cierre social» que determinados sectores de las élites urbanas aplicaron a quienes amenazaban su posición dominante.

Las crónicas recogen la intervención del prior ante los jefes de la revuelta, dejando clara su posición como seńor del lugar. En ningún momento se les reconoce como representantes de la comunidad. Es evidente que el Monasterio, encarnado en su prior, ejerce (o pretende mostrar la imagen de que así es) la representación de los vecinos. Otra muestra, más clara si cabe, del deseo de los priores de ejercer el control es la presencia de un juez corregidor $^{38}$; figura ausente hasta la fecha en la sociedad guadalupense. Fernando Yáñez debió

36 AMG. Legajo 117, n. ${ }^{\circ} 62$.

37 «E quando esto sopo el prior ferrandiánnez, fizolos llamar, e con mucha mansedumbre dixoles, Onbres buenos sabed que me han dicho que algunos de vosotros» (RAE. RM-78, fol. XVv).

38 En 1408 se realiza un traslado de una provisión de Juan II confirmando la exención de monedas de 1407. Pasó ante Pero Díaz de Paterna, bachiller en leyes, «juez e corregidor en la dicha puebla e lugar por el prior del dicho monesterio de santa maria» (AHN. Clero. Legajo 1422, n. ${ }^{\circ} 20$ ). 
disponerlo para un control más efectivo de los grupos insumisos (para lo cual contaría con amplias funciones judiciales y de policía). No debe sorprendernos que todos los testigos del traslado fuesen personal al servicio del Monasterio. También conviene recalcar que el citado juez era una persona totalmente extraña a la comunidad. Un ejemplo de la incorporación de personal foráneo que sustituirá a la oligarquía local rebelde.

$\mathrm{Al}$ despuntar el siglo xv se evidencian dos cambios. El núcleo de gobierno concejil ve progresivamente reducida su actividad a cuestiones directamente relacionadas con la comunidad, reservándose los priores la gestión directa de los asuntos «externos». En segundo lugar, la ruptura del equilibrio de fuerzas entre la vieja y la nueva oligarquía, proceso relativamente rápido que apenas se extendió un sexenio después del motín.

Esto no quiere decir que no existiese un grupo de personas que, siempre por delegación del señor, se encargase de la gestión directa de los asuntos públicos. El mismo prior parece reconocer y sancionar esta situación en 1408 cuando dispuso que se hiciese relación de todos los vecinos que debían pagar los tributos reclamados por el rey en fecha anterior, encargando el cometido a un grupo de «onmes buenos e de buena fama e vezinos ${ }^{39}$. $\mathrm{Al}$ revisar sus nombres comprobamos que se trataba de miembros de la élite del momento.

Sin embargo, podemos destacar un aspecto relevante. Varios de los procuradores designados también son personas ajenas a la comunidad. Su nombramiento evidencia las dificultades de las autoridades eclesiásticas para recomponer el grupo de intermediarios, encargados de gestionar el gobierno diario de la Puebla en su nombre. La falta de apoyos entre la oligarquía local llevaría a seleccionar a sus agentes ejecutores incluso entre recién llegados a la Puebla, que carecían de arraigo en la comunidad. Esto permite plantear que en esta fecha la élite anterior (la vieja oligarquía) se encuentra desarticulada. Una parte aún se mantiene próxima a la autoridad prioral, posiblemente procedente del sector "pro Monasterio", pero tiene que ceder su lugar a una pujante nueva oligarquía aupada al poder por los nuevos señores.

Este cambio en el juego de relaciones parece confirmarse en los años posteriores. En 1410 se otorgó otra carta de procuración, esta vez para arrendar a Talavera la parte de Los Ibañazos ${ }^{40}$. Los procuradores designados son cargos públicos nombrados por el prior, no relacionados con los grupos familiares de la vieja élite; además, la mayoría de los testigos de 1410 eran los mismos que los de 1409. En 1412 Juan II eximió a los vecinos de Guadalupe del pago de las alcabalas. El privilegio se dió a conocer por pregón en la Puebla el 28 de febrero ${ }^{41}$. Estuvieron presentes nueve testigos. Demasiados para este acto, lo que nos lleva a plantear que se trataba del grupo de gobierno, reunido para dar mayor solemnidad. La relación de personas revela que el cambio en la relación de fuerzas había llegado a su fin. Con la salvedad de Gonzalo Fernández, tejero, al que vimos actuar en 1406 y podía ser un representante del antiguo sector "pro Monasterio", ninguno de los citados procedía de la vieja oligarquía. Son personas que prestaban servicio al Monasterio seleccionadas al margen de la élite anterior.

39 AHN. Clero. Legajo 1423, n. ${ }^{\circ} 39$.

40 AMG. Legajo 111, n. 3.

41 AHN. Clero. Legajo 1422, n. ${ }^{\text {s }} 30$ y 33. 


\section{ALFONSO DOMÍNGUEZ DE LA CONCHA

En ningún momento son identificados como concejo o como hombres buenos. El monasterio prescinde de esta institución y ejercerá el poder directamente, utilizando a personas de su confianza como agentes ejecutores de sus decisiones. La presencia entre ellos de Pero González "Gigante» nos revela además otra característica de esta nueva oligarquía, la incorporación de conversos al grupo de gobierno ${ }^{42}$. La selección de personal cualificado es una tendencia que se manifestaba desde hacía décadas, pero la creciente complejidad de la administración de sus bienes y de los asuntos públicos reforzará aún más esta situación; y la minoría judeoconversa mostró siempre una mayor capacidad para la gestión.

\subsection{La crisis de la élite local (1425-1531)}

Los sucesos de 1406 rompieron el acuerdo tácito entre ambos grupos de poder, que había permitido mantener un cierto equilibrio entre las partes. A partir de la segunda década del siglo xv el Monasterio desplegará todos sus recursos para quebrantar al oponente.

El programa político de los priores, dirigido a menoscabar las bases políticas y económicas de la oligarquía, se concretará en una serie de medidas legales, dictadas en ejercicio de su potestad jurisdiccional. Se aprecia, por ejemplo, en la confección de las ordenanzas municipales. Debieron existir desde mucho antes, pero será durante el priorato de fray Gonzalo de Ocańa (1415-1429) cuando se pongan por escrito. Su preámbulo es toda una declaración de intenciones y representación acabada del modelo de sociedad que los priores regulares quieren imponer:

Yo fray Gonzalo de Ocanna prior del dicho monesterio de Sta $\mathrm{Ma}^{\mathrm{a}}$ de Guadalupe con acuerdo e consentimiento de los frayles e convento del dicho monesterio cuya es la dicha Puebla fize e ordené çiertas leyes e cosas para procomún desta Puebla de los vezinos e moradores della vasallos del dicho monesterio e de los otros que a ella van e vienen.

Los priores negaban toda capacidad de intervención a quienes consideraba sus vasallos. Los hombres buenos veían anulado uno de los cauces para influir sobre sus convecinos. La eliminación de cualquier grupo de poder que pudiese cuestionar su autoridad dará un paso más con la «ordenanza contra los que se dicen caballeros» (vid. Apéndice 2), incluida en la recopilación; un ataque directo a los privilegios de la pequeńa nobleza local. El interés de los priores de Guadalupe por no permitir que se consolidase una oligarquía nobiliaria se debería tanto a la competencia directa que este grupo podía representar para el ejercicio del poder, como a la conflictividad que podía generar (en las luchas internas por hacerse con los cargos y en las luchas contra el Común; la búsqueda

42 Fueron varios los miembros de la familia «Gigante» procesados durante la Inquisición de 14841485: Fernando González «Gigante», escribano; su mujer, Beatriz Núñez; y Manuel González, hijo del primero. También consta la condición de converso de Alfonso Fernández «Gigante», padre de Fernando (FITA, Fidel. «Documentos inéditos, anteriores al siglo xvi, sacados de los archivos de Talavera de la Reina». Boletín de la Real Academia de la Historia, 1883, vol. 2, pp. 309-338 [337]). 


$$
\begin{gathered}
\text { ALFONSO DOMÍNGUEZ DE LA CONCHA } \\
\text { ASCENSO Y DECLIVE DE LA ÉLITE RURAL DE LA PUEBLA DE GUADALUPE (CÁCERES) } \\
\text { DURANTE LOS SIGLOS XIV Y XV }
\end{gathered}
$$

de apoyos de uno y otro bando entre los pecheros, romperían el equilibrio de fuerzas y la estabilidad social, comprometiendo la gobernabilidad).

Además, como agresión a las bases económicas de la élite local, dentro de las ordenanzas se incluye una que regulaba el retorno al Monasterio de aquellas tierras que permaneciesen cuatro ańos sin cultivar (vid. Apéndice 1). Como en el caso anterior, los hombres buenos no tuvieron la menor participación en una norma que suponía un quebranto de su patrimonio fundiario. La dificultad para mantener en explotación sus extensas propiedades (por la escasez de mano de obra debida a crisis demográficas y por la pérdida de recursos económicos para contratarla) les llevaría a aceptar su venta al monasterio y sacar al menos un beneficio económico inmediato. No debe extrańarnos que a partir de estas fechas se produjera una oleada de ventas de explotaciones propiedad de las familias terratenientes.

El desplazamiento definitivo de la vieja oligarquía se consumó antes de finalizar el primer tercio del siglo xv. En la inquisición sobre el pasto del término de Acedera $(1418)^{43}$ y en el pleito con la Mesta por el trazado de una cañada en tierras del cenobio $(1425)^{44}$ el Monasterio nombró procuradores seglares, pero ninguno de ellos se puede asociar a la élite anterior.

Todo apunta a que en estas fechas las autoridades eclesiásticas reservan el uso del término hombre bueno a quienes ejerciesen de testigos u otorgantes en un momento dado, en el ejercicio de un vago papel de representantes de la comunidad, en asuntos que les corcenían directamente, sin que tuviese implicaciones sociales más definidas, ni estuviese ligado a un determinado grupo social.

La comunidad no mostrará la misma actitud y durante un tiempo siguió empleando la expresión para designar a una minoría, a la que posiblemente reconocía un cierto protagonismo y preeminencia. Así, en 1420, en el testamento de Martín Sánchez, se identifica a los testigos como "onmes buenos que estavan presentes» ${ }^{45}$. Pero se trata de un espejismo. Hacia 1425 es patente la debilidad de su posición en la estructura social de Guadalupe. Aun así, en el testamento de María Domingo (1426) los testigos todavía son identificados como hombres buenos ${ }^{46}$. Será la última vez que se utilice esta expresión. Este dato es coincidente con otra documentación manejada y muestra que al finalizar el primer cuarto del siglo xv esta institución social estaba desbaratada y había perdido su razón de ser.

Pese a todo ello, la documentación posterior trasluce la existencia de una diferenciación interna del grupo pechero y de un pequeño grupo con capacidad de representación; siempre dentro de parámetros de ambigüedad y perfiles poco definidos. En 1476, tras los tumultos ocurridos cuando sacaron a un hombre de la cárcel, el prior fray Diego de París encomendó una pesquisa a tres omes buenos ${ }^{47}$. Los conflictos se sucedieron y ese mismo año se encargó una información sobre los sucesos ocurridos tras el repartimiento de las

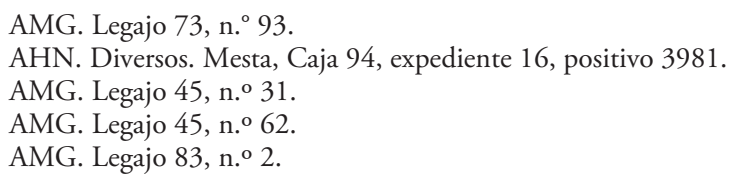


ALFONSO DOMÍNGUEZ DE LA CONCHA

ASCENSO Y DECLIVE DE LA ÉLITE RURAL DE LA PUEBLA DE GUADALUPE (CÁCERES)

DURANTE LOS SIGLOS XIV Y XV

costas en que fueron penados los vecinos tras el pleito con el arcediano de Plasencia ${ }^{48}$. Al parecer para pagar la multa y costas el prior mandó llamar a «muchos hombres honrados» y les propuso repartir los gastos entre todos los vecinos, y lo tuvieron a bien. No pensó lo mismo el resto de la población y se sublevaron. Es manifiesta la contraposición de actitudes. ¿Implica esto un distanciamiento entre la minoría de hombres buenos y la mayoría pechera? Si los hombres honrados mencionados se integraban en la nueva oligarquía se entiende que se alineasen con los intereses del Monasterio (que no quería pagar los gastos del pleito). La mayoría pechera se sentiría traicionada. Esto no haría sino atizar el distanciamiento entre ambos sectores.

Un dato ofrecido por uno de los declarantes en el interrogatorio es revelador del estado de cosas en relación con la élite local. El prior ordenó prender a los cabecillas de los tumultos. Al recibir la noticia de que los hombres del prior estaban deteniendo a sus camaradas, varios de ellos deciden armarse y salir del pueblo para ofrecer resistencia. Reclamaron el apoyo de sus convecinos "pensando que les acudiría mucha gente e non salieron nin osaron salir más de veynte e seys o de veynte e siete onbres». La falta de respaldo popular es evidente. Han perdido su capacidad para aglutinar los intereses y aspiraciones del pueblo y para canalizar su acción.

Ante la contestación social, las autoridades eclesiásticas cerrarán cada vez más el círculo del personal de confianza en quien delegar. En la toma de posesión de la heredad de Pero Blasco (1479) intervienen dos frailes, acompańados del alguacil y varios familiares del Monasterio ${ }^{49}$; no hay representantes de la élite, sea vieja o nueva. Con motivo de la sentencia y posterior amojonamiento del término de Guadalupe con el de Talavera en 1498 se acude a vecinos de la Puebla que son absolutos desconocidos ${ }^{50}$ (la estructura de gobierno ha quedado desmantelada tras los procesos inquisitoriales de 1484-1485 y ya no existe una élite a la que acudir). Cuanto más se estrecha el círculo de personas de confianza, favoreciendo la fidelidad sobre otros criterios, mayor es el desencuentro entre esta minoría y el resto de los vecinos. A comienzos del siglo XVI estos adeptos al prior ya no se encuadran en la élite local, que ha desaparecido, consecuencia de la política del Monasterio, que ha favorecido un empobrecimiento homogeneizador. Los futuros "procuradores» de los vecinos lo serán a título particular (los vecinos no se sienten representados por ellos). Esto aviva el desapego y la falta de cohesión social.

Ya en el siglo Xvi, en la sentencia de 1510 al pleito entre los vecinos de la Puebla y el Monasterio ${ }^{51}$ se dice que el grupo de litigantes que inicio el proceso actuó en nombre de la Puebla. Pero el desarrollo posterior presenta a estas personas como parte interesada, no como procuradores o representantes del resto de los vecinos.

En un último eslabón de este proceso, el prior dictará una sentencia arbitral en 1513 para responder a unas peticiones de los vecinos ${ }^{52}$. Por parte vecinal se trata de limitar o suavizar los efectos de la sentencia de 1510. En primera instancia el escrito lo presentó

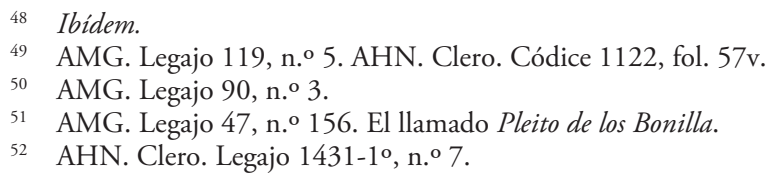




$$
\begin{gathered}
\text { ALFONSO DOMÍNGUEZ DE LA CONCHA } \\
\text { ASCENSO Y DECLIVE DE LA ÉLITE RURAL DE LA PUEBLA DE GUADALUPE (CÁCERES) } \\
\text { DURANTE LOS SIGLOS XIV Y XV }
\end{gathered}
$$

el Procurador de la República. Ante la falta de representantes propios, los vecinos tienen que acudir a un oficial designado por la autoridad seńorial. De esta manera el prior logra encauzar el conflicto hacia ámbitos de actuación y toma de decisiones que controla. E indirectamente implica la desautorización por los vecinos de otras vías de representación.

Ante la falta de respuesta por parte del prior, dos de los vecinos tomaron la iniciativa y presentaron de nuevo un escrito con las peticiones. Pero el movimiento vecinal está descabezado e inerme. Aunque se presenten como procuradores del colectivo, nada se dice del procedimiento de elección o del proceso seguido para fijar la voluntad vecinal plasmada en el escrito. Por el contrario, los presentes, con un lenguaje sumiso que es toda una declaración de pleitesía, reconocen la autoridad prioral y juran someterse a su decisión. Por otro lado, no cuestionan lo dispuesto en la sentencia de Granada, gravemente lesiva para sus intereses, y solo tratan de salvar lo que se pueda.

No debe extrańarnos que en 1521 todos los escritos de agravios por las obras de la Enfermería Nueva ${ }^{53}$ se presenten directamente por los afectados y no fuesen canalizados a través de sus representantes.

Aún en 1529 tres vecinos trataron de soliviantar al pueblo, para que no pagasen el servicio exigido por el prior ${ }^{54}$. Se trata de acciones puntuales, que, como ocurrió en 1476 , carecieron de respuesta popular. Estos tres personajes tendrán una activa participación durante el llamado Pleito de los Gago, una extensión del Pleito de los Bonilla iniciado en 1507. Que alcanzará el mismo resultado.

\section{Conclusiones}

La élite rural de Guadalupe se caracterizó por su heterogeneidad y por ser un grupo dinámico, en permanente transformación. Durante el siglo XIV se constituyó a partir de múltiples vías de acceso: algunos miembros procedían de núcleos de población cercanos, donde ya ocuparían un lugar destacado; otros se integrarían en el círculo de amistades o familiares más próximo al prior; la participación en instituciones de ámbito comarcal serviría de trampolín para el ascenso social y, desde mediados del siglo xIV, la cada vez mayor complejidad y especialización de los asuntos públicos y la administración del patrimonio favorecería la incorporación de personal administrativo con formación académica. En todos lo casos su promoción social estuvo ligada al servicio a los priores, fundamentalmente en labores de representación. En estas fechas sí se puede decir que tienen en común formar parte del segmento más enriquecido de la sociedad. Contaban con el reconocimiento de sus convecinos y se distinguen de ellos con la denominación de hombres buenos.

El desarrollo económico, impulsado con la concesión de feria y mercados, amplió el espectro social de la élite. Posibilitó el ascenso de grupos de artesanos y comerciantes. Estos grupos emergentes, conscientes de su poder económico y social, se integraron en el grupo de gobierno de la Puebla. El término hombre bueno ya no equivale a labrador o

53 AHN. Clero. Legajo 1424/e-3 y sucesivos.

54 AHN, Códices, L. 111, fols. 77v-78r. Extracto. 
terrateniente. Designaría a quienes ejercen funciones de representación de la comunidad, con independencia de su actividad campesina, artesana o comercial.

Esta heterogeneidad dificulta la definición de unos perfiles concretos para este grupo. A finales del siglo xIV ni siquiera tienen en común una posición económica estable. Serán su capacidad para intervenir en los asuntos de la comunidad, la de intermediación con los señores y los aspectos religiosos o devocionales los que les confieran prestigio ante sus convecinos y, por ende, el reconocimiento de su posición social.

La larga experiencia en los asuntos públicos llevó a la élite a tomar conciencia de su capacidad de intervención. Y aprovechó un momento de debilidad del control ejercido por los priores seculares para tratar de reafirmar su autonomía. Este proceso, que estaba en trance de consolidarse a finales del XIV, se vió truncado con la fundación del Monasterio de Nuestra Señora de Guadalupe. Los Jerónimos aplicarán un programa político y económico que afectará profundamente la posición de la élite local, a la red de vínculos preexistente y, en consecuencia, al papel ejercido por aquella dentro de la comunidad rural. En un primer momento los priores regulares toleraron, y en algún caso incorporaron, la presencia de miembros de esta élite anterior, otorgándoles un papel de meros ejecutores de sus disposiciones o una vaga representación de los vecinos en asuntos que les concernían directamente. Pero los vínculos de dependencia acabaron tornándose en relaciones de conflictividad cuando la política del Monasterio desplazó a la vieja oligarquía como interlocutora entre el señor y la comunidad. En su lugar los priores establecieron medidas legales que hacían difícil que se pudiese consolidar una élite rural independiente.

El fracaso de la oligarquía en Guadalupe por mantenerse en el poder se debió también a su debilidad interna, política y económica. Su ascenso y consolidación como grupo en el poder dependía, en úlima instancia, de la voluntad de los priores. Si estos decidían elegir o promover a otros, generando su propia red clientelar, la oligarquía no puede evitarlo -sería luchar contra el mismo sistema que les encumbró-. Las tensiones internas por el control del concejo y su posible condición de cristianos viejos o nuevos no hicieron sino agravar la fractura interna y debilitar su posición. Otro aspecto de esta cuestión es que la oligarquía local de Guadalupe no fue capaz de organizar una red social centralizada en torno a una persona o grupo. Por el contrario, surgieron distintos polos o centros de acción (enfrentamientos internos) que dispersaron y debilitaron su capacidad de acción unitaria.

Otro factor fue la pérdida de una base económica sólida que les brindase capacidad para influir en la comunidad. Al carecer de recursos para participar en el entramado de relaciones y vínculos sociales perderán protagonismo y prestigio. Ya no cumplen las funciones tradicionalmente desempeñadas y desaparecen como institución social.

La primera élite rural de Guadalupe, en cuanto agentes de la autoridad señorial, pudo ejercer una cierta dominación al conseguir una hegemonía estratégica en las redes de relaciones privadas. El proceso, manifestado en Guadalupe a lo largo de la segunda mitad del XIV y primer cuarto del XV, se interrumpe y acaba por desaparecer a lo largo de la primera mitad del xv. El monasterio recuperará las funciones antes asumidas por la vieja oligarquía (los poderes delegados por los priores seculares; la capacidad para 
intervenir en las redes de relaciones privadas), que entregará parcialmente a la nueva oligarquía, ejecutora de su política, pero sin capacidad decisoria.

En el tránsito entre los siglos XV y XVI culminará el proceso de desestructuración social y ruptura de la red de vínculos. La comunidad se ha homogeneizado y apenas quedan elementos que permitan defender la existencia de una minoría dirigente y representativa, que aglutinase la acción colectiva. Y los escasos ejemplos de procuradores o representantes documentados hacen referencia a personas que actúan por iniciativa propia y carecen de características, requisitos o funciones definidas. Ante la ausencia de una minoría dirigente, el fracaso en las acciones legales contra el señorío era inevitable.

\section{ApÉNDICE DOCUMETAL}

1

1424, marzo, 19. GUADALUPE.

Ley sobre las tierras de pan llevar.

\section{A.M.G. Códice 76}

Sepan todas las personas vezinos e moradores desta Puebla del mono de Sta Ma de Guadalupe que agora son e serán de aquí adelante e otras qualesquier a quien lo de yuso escripto atanniere o pertenesçer pueda que por quanto esta Puebla tiene poco término para plantar e senbrar e sy non se labrare e senbrare e plantare lo que buenamente dello se debe e puede senbrar e plantar que dende se puede seguir grand agravio e perjuyzio a esta dicha Puebla e a los vezinos e moradore della lo qual de cada día paresçe. E conmoquier que sobre esto e lo que ayuso será declarado ay ley e ordenaçión antigua de los padres anteçesores de nuestro sennor el prior notoria a todos los sobredichos vezinos e moradores desta dicha Puebla la qual es usada e acostunbrada en ella de mayor tienpo acá de treynta e quarenta e aun de çinquenta annos. Por mayor abondamiento por que por abentura algunas personas que nuevamente son venidas a morar a esta dicha puebla non saben de la dicha ley e ordenaçión e costunbre antigua, manda e tiene por bien que qualesquier personas de las sobre dichas que de presente tienen algunas tierras de labrança para pan o matas o tierras otras para poner e plantar vinnas e árboles perteneçientes o tovieren de aquí adelante, que sy las dichas tierras de labrança o parte alguna dellas dexare por labrar e senbrar quatro annos continuos e por sý mesmos e por sus espensas propias non las labrare. Eso mesmo las personas que las dichas matas e tierras tienen o tovieren de aquí adelante las quales son para poner e plantar vinnas e árboles non las plantaren todas en los quatro annos primeros seguientes e dexare alguna cosa dello por plantar e poner vinnas o otros árboles convenientes para levar fruto, por ese mesmo fecho tornen al dicho monesterio las dichas tierras e labranças e otras tierras e matas del qual son e le pertenesçe según los previllejos que tiene e otrosý segund la dicha ley e ordenaçión e costunbre. E esto por que el dicho sennor prior las pueda dar e fazer dellas conmo la su merçed fuere para que cunplan lo sobredicho. E esta dicha Puebla sea mejor proveýda segund que esto e otras cosas más largamente se contiene en la dicha ley e ordenaçión. Por que puedan dexar las sobredichas personas en las tierras e matas que 
ALFONSO DOMÍNGUEZ DE LA CONCHA

ASCENSO Y DECLIVE DE LA ÉLITE RURAL DE LA PUEBLA DE GUADALUPE (CÁCERES)

DURANTE LOS SIGLOS XIV Y XV

asý tovieren algund poco de tierra por poner e por labrar en el lugar que entendieren para las cosas que fueren nesçesarias e convenientes para proveymiento de las otras tierras e labranças e plantas. Por que sy algunas biudas e huérfanos o algunos viejos desta dicha Puebla que ovieren mayor hedat de çinquenta annos tovieren algunas tierras e labranças e las non podieren labrar e senbrar por sý mesmos nin por sus tutores e administradores o por algund menester que tengan, sepan que el dicho sennor prior por les fazer merçed e limosna les da liçençia para que puedan arrendar o dar a terradgo las tales tierras a los vezinos e moradores desta dicha Puebla. E otrosý sepan que el dicho sennor prior dize que por lo que suso dicho es non entiende yr contra la dicha ley e ordenaçión antigua usada e acostunbrada e guardada en esta dicha Puebla del dicho [espacio en blanco] acá. La qual es que persona alguna non pueda labrar en el dicho término syn liçençia del prior del dicho mon o o de su lugarteniente, e las tierras que labraren que las non puedan vender ni trocar nin arrendar nin donar nin enajenar en alguna manera. E sy lo fesiere que por eso mesmo fecho pierda las tierras e el presçio que por ellas fuere dado sea perdido e sea destribuydo donde el dicho sennor prior mandare. E eso mesmo el dicho sennor prior manda çerca de las otras tierras e labranças e matas que tienen en qualquier manera las sobredichas personas seguiendo e guardando la dicha ley e ordenaçión e antigua costunbre que non puedan ser vendidas nin enajenadas en manera alguna so la dicha pena. E demás desto que qualquier que contra ello fuere que sea obligado a las penas corporales e pecuniarias que a la merçed del dicho sennor prior le quisiere mandar dar e poner asý a los cuerpos conmo en la fazienda por yr contra su mandamiento e ley e ordenaçión e costunbre antigua, segund dicho es. Todo lo qual e cada cosa dello el dicho sennor prior lo manda de presente e declara e ordena a mayor abondamiento conmo dicho es e quiere e tiene por bien que sea asý guardado e tenido e conplido por todas las dichas personas. E por que desto fuesen todos çiertos e sabidores e non pudieren allegar nin presentar ygnorançia, mandó dar esta carta firmada de su nonbre. E sellada en las espaldas con el sello de la su abdiençia. E mandó otrosý que fuese pregonada públicamente en la plaça desta dicha Puebla. Dada en esta dicha Puebla diez e seys días de março anno del nasçimiento del nuestro sennor ihu xpo de $\mathrm{M}$ cccc e xx iiij annos. Frater gundisalvo prior de guadaluppe.

2

c 1444-1447. GUADALUPE.

Ordenanzas sobre los caballeros e hidalgos.

AMG. Códice 76.

(...) Santa María de Guadalupe por (...) e leyes e sançiones del sennor rrey (...) se arman cavalleros del queriendo asý (...) por lo qual se disen esentos e non ser obligados a pagar los pechos tributos e derechos devidos al dicho monesterio por todos los otros vesinos del dicho lugar en lo quel dicho mon ${ }^{\circ}$ resçibe grande agravio e perjuiçio e espera del mayor para adelante $\mathrm{E}$ a los vesinos e moradores del dicho logar sería cabsa de mucha discordia e turbaçión sy çerca de los tales non se pusyere algund remedio/ E por ende yo fray Juan de Çamora prior del dicho mon ${ }^{\circ}$ avida deliberaçión sufiçiente e consejo e consentimiento de los deputados e (...) por mayor abondamiento del convento del dicho mono /. Ordeno e 


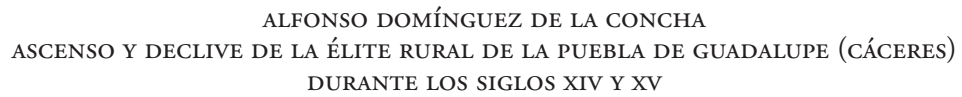

establesco que sy alguno de los vezinos e moradores del dicho lugar que agora son o seran de aquí adelante se fizieren armar cavallero o ganare algund týtulo de fydalguía sy dende algún mes non paresçiere delante mý o del prior que por el tienpo fuere con escribano público E non se obligare e fysiere juramento de pagar todos los pechos tributos e derechos que los otros vezinos e moradores del dicho lugar pagaren renunçiando en esta parte al privilegyo o execuçión de la cavallería o fidalguía que sea lançado del dicho lugar e privado de la vezindad dél / E sy después que por mí o por alguno de mis suçesores le fuere mandado que se vaya del dicho lugar / por cada día después del término asygnado que en él estoviere aya en pena de çient mrs la meytad para el que lo acusare e la otra meytad para provecho de la re pública E demás desto fynque poderío al prior que fuere a la sazón que le ponga las penas que quisiere e bien visto le fuere/. E otrosý establezco e ordeno que sy de mi liçençia o de alguno de mis subçesores algund cavallero o fidalgo fuere resçibido por vezino del dicho lugar E dende algún mes non se obligare e fyziere juramento de pagar todos los pechos e tributos e derechos que los otros vesinos pagaren segund su que dicho es sea alcançado del dicho lugar e privado de la vezindad dél e incurra en la dicha pena de los çient mrs por la forma e manera suso contenida.

\section{REFERENCAS BIBLIOGRÁFICAS}

Alfonso, Isabel (coord.): La historia rural de las sociedades medievales europeas: tendencias y perspectivas. València: Universitat de València, 2008.

Alfonso Antón, Isabel. «Poder local y diferenciación interna en las comunidades rurales gallegas». En PAStor, Reyna (comp.). Relaciones de poder, de producción y parentesco en la Edad Media y Moderna. Aproximación a su estudio. Madrid: Consejo Superior de Investigaciones Científicas, 1990, pp. 203-223.

Aparisi Romero, Frederic. "Las élites rurales en la Edad Media como objeto de estudio: de la marginalidad al centro del debate historiográfico». Historia. Instituciones. Documentos, 2013, vol. 40, pp. 11-34.

Aparisi Romero, Frederic. "The notarial profession as a means of social promotion amongst rural elites in the midlands of the Kingdom of Valencia during the Later Middle Ages». En Aparisi, Frederic y Royo, Vicent (eds.). Beyond Lords and Peasants. Rural elites and Economic Differentiation in Pre-Modern Europe. València: Universitat de València, 2014, pp. 139-162.

Aparisi, Frederic y Royo, Vicent (eds.). Beyond Lords and Peasants. Rural elites and Economic Differentiation in Pre-Modern Europe. València: Universitat de València, 2014.

Astarita, Carlos. «Representación política de los tributarios y lucha de clases en los concejos medievales de Castilla». Studia Historica. Historia Medieval, 1997, vol. 15, pp. 139-169.

Astarita, Carlos. Del feudalismo al capitalismo. Cambio social y politico en Castilla y Europa occidental: 1250-1520. València: Universitat de València, 2005.

Borrero Fernández, Mercedes. «Élites rurales y mercado en la Andalucía bajomedieval». En Pautes de consum i nivells de vida al món rural medieval. Coloquio Internacional. València: Univiversitat de València, 2008, disponible en http://www.uv.es/consum/textos.htm

Carvajal de la Vega, David; AÑíbarro Rodríguez, Javier y Vítores Casado, Imanol (eds.). Redes sociales y económicas en el mundo bajomedieval. Valladolid: Castilla Ediciones, 2011.

Casado Alonso, Hilario. "Solidaridades campesinas en Burgos a fines de la Edad Media». En Pastor, Reyna (comp.). Relaciones de poder, de producción y parentesco en la Edad Media y 
Moderna. Aproximación a su estudio. Madrid: Consejo Superior de Investigaciones Científicas, 1990, pp. 279-304.

Cerro Herranz, M. ${ }^{a}$ Filomena. Documentación del monasterio de Guadalupe. Siglo XIV. Badajoz: Departamento de Publicaciones de la Excma. Diputación Provincial de Badajoz, 1987.

Diago Hernando, Máximo. «Comerciantes campesinos en la Castilla bajomedieval y moderna: la actividad mercantil de los yangüeses entre los siglos XIV y XVII». Historia. Instituciones. Documentos, 2005, vol. 32, pp. 115-144.

FiTA, Fidel. «Documentos inéditos, anteriores al siglo Xvi, sacados de los archivos de Talavera de la Reina». Boletín de la Real Academia de la Historia, 1883, vol. 2, pp. 309-338.

Furió, Antoni. «Las élites rurales en la Europa medieval y moderna. Una aproximación de conjunto». En Rodríguez, Ana (ed.). El lugar del campesino. En torno a la obra de Reyna Pastor. Valencia: Consejo Superior de Investigaciones Científicas, 2007, pp. 391-421.

García Oliva, M. a Dolores. Organización económica y social del concejo de Cáceres en la Baja Edad Media. Cáceres: Institución Cultural El Brocense. Excma. Diputación Provincial de Cáceres, 1990.

Goicolea Julián, Francisco Javier. «Sociedad y relaciones de poder en una ciudad riojana a fines del Medievo: Santo Domingo de la Calzada». Espacio, Tiempo y Forma. Serie III, H. ${ }^{a}$ Medieval, 1999, vol. 12, pp. 243-286.

Graña Cid, María del Mar. "Urbanización y conexiones con el medio agrario durante la Baja Edad Media: el ejemplo de la villa alcarreña de Cifuentes». En la España Medieval, 1992, vol. 15, pp. 121-135.

Imízcoz Beunza, José María. «Comunidad, red social y élites. Un análisis de la vertebración social en el Antiguo Régimen». En Imízcoz, José María (dir.). Élites, poder y red social. Las élites del País Vasco y Navarra en la Edad Moderna. Bilbao: Universidad del País Vasco, 1996, pp. 13-50.

Imízcoz Beunza, José María. «Las redes sociales de las élites. Conceptos, fuentes y aplicaciones». En Soria Mesa, Enrique; Bravo Caro, Juan Jesús y Delgado Barrado, José Miguel (eds.). Las élites en la época moderna: la monarquía española. Vol. I: Nuevas perspectivas. Córdoba: Universidad de Córdoba, Servicio de Publicaciones, 2009, pp. 77-112.

Lorenzo Cadarso, Pedro Luis. Los conflictos populares en Castilla (siglos XVI-XVII). Madrid: Siglo XXI de España Editores, 1996, pp. 147-148.

Luchía, Corina. «Dos memoriales de agravios de Ciudad Rodrigo: el diálogo político entre pecheros, élites y monarquía en torno del ejercicio del poder». Actas y Comunicaciones del Instituto de Historia Antigua y Medieval, 2013, vol. 9, pp. 1-15.

Martín Cea, Juan Carlos. El mundo rural castellano a fines de la Edad Media. El ejemplo de Paredes de Nava en el siglo XV. Valladolid: Junta de Castilla y León, 1991.

Martínez Sopena, Pascual. La Tierra de Campos Occidental. Poblamiento, poder y comunidad del siglo X al XIII. Valladolid: Institución Cultural Simancas. Diputación Provincial de Valladolid. 1985.

Menant, François y Jessenne, Jean-Pierre (eds.). Les élites rurales dans l'Europe médiévale et moderne. Toulouse: Presses Universitaires du Mirail, 2007.

Mondragón, Silvina Andrea. «Participación política de pecheros en Castilla tardomedieval: los posibles márgenes de acción entre la diferenciación socioeconómica del sector y la imposición de concejo cerrado". Espacio, Tiempo y Forma. Serie III, H. a Medieval, 2012, vol. 25, pp. 309-326.

Monsalvo AnTón, José María. «La participación política de los pecheros en los municipios castellanos durante la Baja Edad Media. Aspectos organizativos». Studia Historica. Historia Medieval, 1989, vol. 7, pp. 37-93. 
ALFONSO DOMÍNGUEZ DE LA CONCHA

ASCENSO Y DECliVE DE LA ÉLITE RURAL DE LA PUEBLA DE GUADALUPE (CÁCERES)

DURANTE LOS SIGLOS XIV Y XV

MuÑoz Gómez, Víctor. «La participación política de las élites locales en el gobierno de las ciudades castellanas en la Baja Edad Media. Bandos y conflictos de intereses (Paredes de Nava, final del s. xIv-inicio del s. xv)». Anuario de Estudios Medievales, 2009, vol. 39/1, pp. 275-305.

Nieto Soria, José Manuel. «Iglesia y orígenes del Estado moderno en la Castilla Trastámara». Espacio, Tiempo y Forma. Serie III, H. ${ }^{a}$ Medieval, 1991, vol. 4, pp. 137-160.

Oliva Herrer, Hipólito Rafael. «Reacciones a la crisis de 1504 en el mundo rural castellano». En Oliva Herrer, Hipólito Rafael y Benito I Monclús, Pere (eds.). Crisis de subsistencia y crisis agrarias en la Edad Media. Sevilla: Universidad de Sevilla, Secretariado de Publicaciones, 2007, pp. 259-275.

Quintanilla Raso, M. ${ }^{a}$ Concepción. «Política ciudadana y jerarquización del poder. Bandos y parcialidades en Cuenca». En la España Medieval, 1997, vol. 20, pp. 219-250.

Rodríguez, Ana María y Pastor, Reyna. "Reciprocidades, intercambio y jerarquía en las comunidades medievales». Hispania, 2000, vol. LX/1, n. ${ }^{\circ} 204$, pp. 63-101.

Sánchez Benito, José María. «Hermandades y delincuencia rural entre el Tajo y Sierra Morena (siglos XIII-Xv)». Clio \& Crimen, 2006, vol. 3, pp. 134-166.

Sánchez Benito, José María. «La Hermandad de los Montes de Toledo entre los siglos XIV-XV». Espacio, Tiempo y Forma. Serie III, H. ${ }^{a}$ Medieval, 2005, vol. 18, pp. 209-229.

SÁnchez Sesa, Rafael. «Don Pedro Tenorio y la reforma de las Órdenes monásticas en el último tercio del siglo xiv. La vinculación del prelado a la espiritualidad jerónima». En la España Medieval, 1995, vol. 18, pp. 289-302.

Schofield, Phillipp R. Peasant and community in late medieval England, 1200-1500. Basingstoke: Palgrave Macmillan, 2003. 
